\title{
Modification of Petunia Seedling Carbohydrate Partitioning by Irradiance
}

\author{
David F. Graper ${ }^{1}$ and Will Healy ${ }^{2}$ \\ Department of Horticulture, University of Maryland, College Park MD 20742
}

Additional index words. lighting, peak photosynthetic photon flux, photoperiod, photosynthetic period, Petunia $\times$ hybrids

\begin{abstract}
Petunia $\times$ hybrida Villm. 'Red Flash' plants received either 10 or 20 mol-day' photosynthetic photon flux (PPF) in growth chambers at: $175 \mu \mathrm{mol} \cdot \mathrm{m}^{-2} \cdot \mathrm{s}^{-1}$ for $16 \mathrm{hours}, 350 \mu \mathrm{mol} \cdot \mathrm{m}^{-2} \cdot \mathrm{s}^{-1}$ for 8 or $16 \mathrm{hours}$, or $350 \mu \mathrm{mol} \cdot \mathrm{m}^{-2} \cdot \mathrm{s}^{-1}$ for 8 hours plus 8 hours of incandescent photoperiod extension $\left(5 \mu \mathrm{mol} \cdot \mathrm{m}^{-2} \cdot \mathrm{s}^{-1} \mathrm{PPF}\right)$. The irradiation components of peak, total, and duration were examined. Doubling total PPF increased total carbohydrate (CHO) production by $60 \%$, seedling dry weight $(\mathrm{DW})$ by $30 \%$, rate of seedling growth by $25 \%$, and acid invertase activity by $50 \%$ compared to the other treatments, once the seedlings had reached the two-leaf stage. Seedlings receiving $20 \mathrm{~mol}^{\circ} \cdot \mathrm{day}{ }^{-1} \mathrm{PPF}$ partitioned $14 \%$ more $\mathrm{CHO}$ into ethanol soluble sugars rather than starch, which may explain the increase in relative growth rate observed with supplemental irradiance treatments. Extending the photoperiod for 8 hours with $5 \mu \mathrm{mol} \cdot \mathrm{m}^{-2} \cdot \mathrm{s}^{-1}$ PPF reduced total CHO production by $50 \%$ compared to the same treatment without photoperiodic lighting. Treatment with $350 \mu \mathrm{mol} \cdot \mathrm{m}^{-2} \cdot \mathrm{s}^{-1}$ for 8 hours resulted in the highest $\mathrm{O}_{2}$ evolution $\left(8.8 \mu \mathrm{mol} \mathrm{O}_{2} / \mathrm{min}\right.$ per $\left.\mathrm{dm}^{2}\right)$. Increasing the photoperiod from 8 to 16 hours gave the lowest rate of $\mathrm{O}_{2}$ evolution $\left(4.5 \mu \mathrm{mol} \mathrm{O}_{2} / \mathrm{min}\right.$ per $\left.\mathrm{dm}^{2}\right)$. Previous reports of the importance of photosynthetic period in controlling partitioning between starch and sugars may have simply observed a decreasing rate of starch accumulation due to increased total PPF.
\end{abstract}

Peak PPF and the photosynthetic (Pn) period are two components of irradiance that are influential in CHO metabolism and transport (Chatterton and Silvius, 1980b; Grange, 1985; Silvius et al., 1979). Elevating peak PPF increased total net photosynthesis $25 \%$ and resulted in a higher rate of soluble CHO translocation within Glycine max L. (Silvius et al., 1979). Transferring G. max plants from 600 to $950 \mu \mathrm{mol} \cdot \mathrm{m}^{-2} \cdot \mathrm{s}^{-1}$ initially increased starch production by $60 \%$, but after a 2 -day lag period, starch production decreased and translocation increased by $20 \%$ (Silvius et al., 1979). Grange (1985) reported higher levels of starch in Capsicum annuum L. as peak PPF was increased. The translocation rate also increased by doubling the Pn period from 7 to $14 \mathrm{~h}$ (Chatterton and Silvius, 1980b). In each of these experiments, peak PPF or Pn period was increased, which resulted in increased net photosynthesis, starch production, or translocation. While peak PPF or Pn period increased, total integrated PPF also increased. Therefore, the reported increases in net photosynthesis, starch production, and translocation may have actually been due, in part, to changes in total PPF rather than peak PPF or Pn period.

Petunias have been the focus of considerable research due to their importance as a bedding plant crop. Much of this earlier research focused on irradiance treatments imposed for extended periods between sowing and flowering (Carpenter and Beck, 1973; Krizek et al., 1974; Merritt and Kohl, 1982; Seeley, 1960). Petunia is a C3 plant reported to be day-neutral before the six-leaf stage (Carpenter and Carlson, 1974), at which time it responds as a long-day plant.

We used Petunia $\times$ hybrida Villm. 'Red Flash' seedlings as a model plant to determine the effects of photoperiod, peak PPF,

\footnotetext{
Received for publication 16 July 1990. Accepted for publication 17 Oct. 1991. Scientific article no. A-6211, contribution no. 8380 of the Maryland Agr. Expt. Sta. Funding for this research supplied by the Maryland Agr. Expt. Sta., Bedding Plant Foundation and Statistical Lab, Sea Grant College, Univ. of Maryland. The cost of publishing this paper was defrayed in part by the payment of page charges. Under postal regulations, this paper therefore must be hereby marked advertisement solely to indicate this fact.

'Currently, Assistant Professor, Dept. of Horticulture, Forestry, Landscape, and Parks, South Dakota State Univ., Brookings.

'Currently, Technical Services Specialist, Ball Seed Co., 622 Town Rd., West Chicago, IL 60185.
}

and total PPF on seedling growth, Pn capacity, CHO metabolism, and invertase activity of seedlings at the two-leaf stage of development. Supplemental irradiance treatments during periods of low ambient insolation in the greenhouse simultaneously increase total PPF, peak PPF, photoperiod, and Pn period. Determining how these factors interact to accelerate photosynthesis and growth rate and alter $\mathrm{CHO}$ partitioning should indicate possible mechanisms involved in hastening seedling growth.

\section{Materials and Methods}

General protocol. 'Red Flash' petunia seed was sown in 288 plug flats (cells, $2 \times 2 \times 3-\mathrm{cm}$ tall; cell, $6.25 \mathrm{ml}$; 288 cells per flat). Before sowing, the flats were filled about one-third full with Redi-Earth peat-lite mix (W.R. Grace and Co., Cambridge, Mass.) and saturated with tap water. About $1.5 \mathrm{~g} / \mathrm{flat}$ of $17 \mathrm{~N}-9 \mathrm{P}-13 \mathrm{~K}(17 \mathrm{~N}-3.9 \mathrm{P}-10.8 \mathrm{~K})$ Osmocote $(9.370 \mathrm{ammo}-$ nium; Sierra Chemical Co., Milpitas, Calif.) was spread uniformly over each flat using an Old Mill seeder (Old Mill Seeder Co., Savage, Md.). The flats were then completely filled with the medium and again saturated with tap water. One seed was then sown per cell with the Old Mill seeder.

The seeded flats were placed in plastic bags and germinated in darkness near 27C until the first cotyledons merged. After removing the bags, two flats, representing two sampling units, were randomly assigned to each of four specially designed PGC model AA-5460A chambers (Parameter Generation and Control, Black Mountain, N. C.) continuously at $21 \pm 1$ C. Flats were rotated within each chamber daily to minimize the effects of light and water distribution patterns.

Plants were irradiated using eight or 16 F48PG17 cool-white fluorescent lamps per chamber, suspended 30 to $50 \mathrm{~cm}$ above the plants, to provide either 175 or $350 \mu \mathrm{mol} \cdot \mathrm{m}^{-2} \cdot \mathrm{s}^{-1}$ at plant level. The lamps were isolated from the plants by a plexiglas barrier in a ventilated light cap. Plants were supplied with either 10 or 20 mol.day ${ }^{-1} \mathrm{PPF}$ using one of the following treatments: $175 \mu \mathrm{mol} \cdot \mathrm{m}^{-2} \cdot \mathrm{s}^{-1}$ for $16 \mathrm{~h}(175 / 16), 350 \mu \mathrm{mol} \cdot \mathrm{m}^{-2} \cdot \mathrm{s}^{-1}$ for 8 $\mathrm{h}(350 / 8)$ or $16 \mathrm{~h}(350 / 16)$, or $350 \mu \mathrm{mol} \cdot \mathrm{m}^{-2} \cdot \mathrm{s}^{-1}$ for 8 -h plus

\footnotetext{
Abbreviation CHO, carbohydrate; DW, dry weight PE, photoperiod extension; Pn, photosynthesis; PPF, photosynthetic photon flux; SLW, specific leaf weight.
} 
an 8-h incandescent photoperiod extension (350/PE) (5 $\left.\mu \mathrm{mol} \cdot \mathrm{m}^{-2} \cdot \mathrm{s}^{-1} \mathrm{PPF}\right)($ Table 1$)$. These treatments were chosen to provide the $1 \times$ and $2 \times$ irradiance levels feasible within the design constraints of the chambers. Flats were mist-irrigated 12 sec every $6 \mathrm{~min}$ for $5 \mathrm{~h}$ each 24 -h cycle beginning $3 \mathrm{~h}$ into the light cycle.

The light cycle within each chamber began at staggered 15min intervals to facilitate the sampling of plants. Sufficient seedling shoots (30 to 50 shoots, cut at the medium surface) at the two-leaf stage were sampled to comprise two 500-mg fresh weight (FWT) subsamples from each flat for $\mathrm{CHO}$ content and $2.5 \mathrm{~g}$ FWT for acid invertase activity analysis. Samples for analysis were collected $2 \mathrm{~h}$ into the light cycle. Plants were designated at the two-leaf stage once the third true leaf had become microscopically visible. Samples for $\mathrm{CHO}$ analysis were frozen at $-70 \mathrm{C}$. Tissue for invertase analysis was placed in cold extraction buffer on ice until all samples were ground. The number of days for the majority of the plants to reach the two-leaf stage and mean seedling DW were recorded.

The experiment was replicated in time with treatments randomly assigned to chambers before each experiment commenced. Treatment means were separated using SAS General Linear Models procedure and single degree-of-freedom comparisons testing for main effects and interactions of the four treatment effects of peak PPF, Pn period, photoperiod, and total PPF as described in Table 1 (SAS Institute, Inc., Cary, N.C.).

Carbohydrate extraction. Tissue was homogenized in $80 \% \mathrm{EtOH}$ using a polytron (Brinkmann Instruments, Westbury, N. Y.) with a $\beta$-phenyl-D-glucoside internal standard. Homogenates were placed in a boiling water bath for $15 \mathrm{~min}$ and centrifuged at $1100 \times \mathrm{g}$ for $10 \mathrm{~min}$. The supernatant was decanted and saved for soluble sugar analysis. The pellet was rinsed three times with $80 \% \mathrm{EtOH}$ and given a final rinsing with distilled, deionized $\mathrm{H}_{2} \mathrm{O}$ (Huber and Israel, 1982). The combined supernatants were evaporated and all volumes were equalized to $2 \mathrm{ml}$ with $\mathrm{H}_{2} \mathrm{O}$.

Sugar analysis. The $2 \mathrm{ml}$ of $\mathrm{CHO}$ extracts were filtered through a 2-cm column of polyvinylpolypyrrolidone to remove phenols, placed into microtubes, frozen in liquid $\mathrm{N}_{2}$, and stored at $-20 \mathrm{C}$ overnight. Samples were thawed, centrifuged at $20,850 \times \mathrm{g}$ for 15 rein, and filtered through a $0.2-\mu \mathrm{m}$ filter disk. Soluble sugars were measured using a gas chromatograph-mass spectrophotometer following TMS (tetramethylsilane) derivation ( $\mathrm{Li}$ and Schuman, 1980).

Starch analysis. The pellet from EtOH soluble sugar extraction was resuspended in $1 \mathrm{ml}$ of $0.2 \mathrm{~N} \mathrm{KOH}$ and boiled for 15 min before the solution was neutralized with $200 \mu \mathrm{l}$ of $1 \mathrm{~N}$ acetic acid. Starch was digested by $1 \mathrm{ml}$ of amyloglucosidase (400 units/ml) in $100 \mathrm{~mm}$ citric acid buffer at pH 5.5. Samples were incubated for $4 \mathrm{~h}$ at $37 \mathrm{C}$ with periodic agitation. Tubes were boiled for $1 \mathrm{~min}$ and centrifuged at $1100 \times \mathrm{g}$ for $5 \mathrm{~min}$ (Beaudry et al., 1989).

Starch content was calculated by measuring glucose content. The glucose oxidase reagent consisted of $60 \mathrm{ml}$ of $200 \mathrm{~mm}$

Table 1. Irradiance conditions in the growth chambers: peak PPF $\left(\mu \mathrm{mol} \cdot \mathrm{m}^{-2} \cdot \mathrm{s}^{-1}\right)$, Pn period $\left(\mathrm{h} \cdot \mathrm{day}^{-1}\right)$, photoperiod $\left(\mathrm{h} \cdot \mathrm{day}^{-1}\right)$, and total PPF $\left(\mathrm{mol} \cdot \mathrm{m}^{-2} \cdot \mathrm{day}^{-1}\right)$.

\begin{tabular}{lcccc}
\hline \hline Treatment & Peak PPF & Pn period & Photoperiod & Total PPF \\
\hline $175 / 16$ & 175 & 16 & 16 & 10 \\
$350 / 8$ & 350 & 8 & 8 & 10 \\
$350 / 16$ & 350 & 16 & 16 & 20 \\
$350 / \mathrm{PE}$ & 350 & 8 & 16 & 10 \\
\hline
\end{tabular}

Hepes- $\mathrm{NaOH}(\mathrm{pH}$ 7), $40 \mathrm{ml}$ glycerol, $6 \mathrm{mg}$ peroxidase, $14 \mathrm{mg}$ dianisidine, and $26 \mathrm{mg}$ glucose oxidase. The glucose content of a 100- $\mu \mathrm{l}$ sample of supernatant was measured. Glucose determination was made by adding $2 \mathrm{ml}$ of glucose oxidase reagent plus $900 \mu \mathrm{l}$ of $50 \mathrm{~mm}$ citric acid buffer at $\mathrm{pH}$ 5.5. Samples were incubated at $37 \mathrm{C}$ for $15 \mathrm{~min}$. Reactions were stopped by adding $4 \mathrm{ml}$ of $5 \mathrm{~N} \mathrm{HCl}$. Glucose was measured by absorbance at $540 \mathrm{~nm}$ (Chatterton and Silvius, 1979).

Invertase analysis. The 2.5-g FWT sample was ground in 50 mm Hepes-NaOH (pH 6.9) using a Polytron. The suspension was filtered through Miracloth, rinsed with additional buffer, and centrifuged for $15 \mathrm{~min}$ at $26,000 \times g$. Supernatant was dialyzed for $12 \mathrm{~h}$ in $10 \mathrm{~mm}$ Hepes- $\mathrm{NaOH}(\mathrm{pH} 6.9)$ at $4 \mathrm{C}$. The solution was replaced and allowed to dialyze an additional $6 \mathrm{~h}$.

Enzyme activity was measured by using $50 \mu \mathrm{l} \mathrm{Na}$-acetate buffer at $\mathrm{pH} 5.5,50 \mu \mathrm{l} \mathrm{H}_{2} \mathrm{O}$, and $50 \mu \mathrm{l}$ enzyme extract. Samples were incubated at $30 \mathrm{C}$ for $5 \mathrm{~min}$ before $50 \mu \mathrm{l}$ of $400 \mathrm{~mm}$ sucrose was added; they then were incubated for $15 \mathrm{~min}$ at $30 \mathrm{C}$. Reactions were stopped by placing samples into an ice bath and adding $1 \mathrm{ml}$ of $100 \mathrm{~mm}$ borate buffer at $\mathrm{pH} 9.0$. Reducing sugar content was then measured at $276 \mathrm{~nm}$ after reaction with 200 $\mu \mathrm{l}$ of $1 \%$ 2-cyanoacetamide (Gross, 1982).

Oxygen evolution measurement. Due to the small size and limited leaf expansion of the seedlings, measurement of Pn rate by $\mathrm{CO}_{2}$ uptake using infrared-gas analysis was not feasible. Therefore, plant Pn capacity was estimated by measuring shoot $0_{2}$ evolution in a Hansatech LD2 leaf disk electrode (Decagon Devices, Pullman, Wash.).

When a large proportion of the seedlings in a treatment reached the two-leaf stage, a section of the flat, with seedlings intact, was removed from the chamber for $0_{2}$ evolution measurement in the laboratory. Representative plants were used for $0_{2}$ evolution measurements. Measurements were made between 2 and $7 \mathrm{~h}$ into the photoperiod, repeating measurements of each of the treatments each 60 to $75 \mathrm{~min}$. The leaves of four entire petunia shoots were carefully oriented in the chamber to allow for uniform irradiation of all leaves by the xenon light source. The general procedures, described by Delieu and Walker (1983) and Walker (1985) were followed with the slight modification of using whole leaves rather than $10-\mathrm{cm}^{2}$ leaf disks for $\mathrm{O}_{2}$ evolution measurement. Two $4.25-\mathrm{cm}$ Whatman \#1 filter paper disks, separated by a layer of cheesecloth, were cut to fit inside the LD2 chamber. This "sandwich" was then saturated with $\approx 0.5$ $\mathrm{ml}$ of a $1 \mathrm{M} \mathrm{KHCO}_{3}$ solution to supply the $\mathrm{CO}_{2}$ necessary for photosynthesis. Seedlings were held in the chamber with the light source in place for 4 to $5 \mathrm{~min}$ before calibration and 0 measurement. Readings were taken each minute until a steady state of $0_{2}$ evolution was observed, usually requiring 8 to 12 $\mathrm{min}$. The xenon light source was operated at $1000 \mu \mathrm{mol} \cdot \mathrm{m}^{-2} \cdot \mathrm{s}^{-1}$ PPF during the measurement. Preliminary observations of $\mathrm{O}_{2}$ evolution revealed that evolution was fairly linear from $\approx 600$ to $1250 \mu \mathrm{mol} \cdot \mathrm{m}^{-2} \cdot \mathrm{s}^{-1}\left(r^{2}=0.83\right)$ in 'Red Flash' petunia seedlings during the sampling period used (data not presented).

\section{Results and Discussion}

Plants in the 350/16 treatment reached the two-leaf stage in $25 \%$ fewer days with $30 \%$ greater DW than those receiving half the total PPF or a similar Pn period (Table 2). Data obtained under 350/16 conditions supported the results from earlier work (Carpenter and Carlson, 1974; Graper and Healy, 1987, 1989; Lang and Healy, 1985) where increased total PPF yielded larger plants in reduced time. Increasing the photoperiod (350/PE) by incandescent day extension failed to decrease the days to reach 
Table 2. Petunia $\times$ hybrida 'Red Flash' seedling characteristics at the two-leaf stage for the four irradiance treatments. (See Table 1 for treatment explanation.)

\begin{tabular}{lcccc}
\hline \hline Treatment & $\begin{array}{c}\text { Days to two- } \\
\text { leaf stage }\end{array}$ & $\begin{array}{c}\mathrm{DW} \\
(\mathrm{mg})\end{array}$ & $\begin{array}{c}\mathrm{SLW} \\
\left(\mathrm{mg} \cdot \mathrm{cm}^{-2}\right)\end{array}$ & $\begin{array}{c}\mathrm{O}_{2} \text { evolution } \\
\left(\mu \mathrm{mol} \mathrm{O} / \mathrm{min} \mathrm{per} \mathrm{dm}^{2}\right)\end{array}$ \\
\hline $175 / 16$ & $16.3 \mathrm{ab}^{2}$ & $2.1 \mathrm{a}$ & $2.6 \mathrm{~b}$ & $6.1 \mathrm{~b}$ \\
$350 / 8$ & $18.2 \mathrm{a}$ & $2.0 \mathrm{ab}$ & $2.8 \mathrm{~b}$ & $8.8 \mathrm{a}$ \\
$350 / 16$ & $14.0 \mathrm{~b}$ & $2.4 \mathrm{a}$ & $3.5 \mathrm{a}$ & $7.5 \mathrm{ab}$ \\
$350 / \mathrm{PE}$ & $17.3 \mathrm{a}$ & $1.4 \mathrm{~b}$ & $1.6 \mathrm{c}$ & $4.5 \mathrm{c}$
\end{tabular}

${ }^{2}$ Mean separation in columns by LSD, $P=0.05$.

the two-leaf stage, but also decreased seedling DW by an average of 55\% compared to 350/16 (Table 2). Lang and Healy (1985) reported that a similar low-level incandescent PE treatment for 7 days decreased seedling DW by $25 \%$ compared to $\mathrm{PE}$ using high-level irradiance at $\approx 85 \mu \mathrm{mol} \cdot \mathrm{m}^{-2} \cdot \mathrm{s}^{-1}$.

In all treatments, leaf areas ranged from 0.7 to $0.9 \mathrm{~cm}^{2} /$ plant. However, $\mathrm{O}_{2}$ evolution was $31 \%$ higher under an 8 -h photoperiod at $350 \mu \mathrm{mol} \cdot \mathrm{m}^{-2} \cdot \mathrm{s}^{-1} \mathrm{PPF}$ than under the $175 / 16$ treatment and was reduced by $48 \%$ in the 350/PE treatment (Table 2). Specific leaf weight (SLW) followed trends similar to $\mathrm{O}_{2}$ evolution, with the 350/PE treatment having the lowest value recorded (Table 2).

Chabot et al. (1979) found Fragaria virginiana (Duch.) SLW increased as peak or total PPF increased. Also, net photosynthesis was increased when the total PPF was increased from 10.09 to $19.98 \mathrm{~mol} \cdot \mathrm{m}^{-2} \cdot$ day $^{-1}$, but not when peak PPF was increased from 105 to $560 \mu \mathrm{mol} \cdot \mathrm{m}^{-2} \cdot \mathrm{s}^{-1}$. Our results show similar trends, with $\mathrm{O}_{2}$ evolution and SLW increasing as total PPF increased (Table 2). However, single degree-of-freedom comparisons of $\mathrm{O}_{2}$ evolution show a significant difference due to photoperiod and Pn period as well (Table 2). This result is due to the effect of the high rate of $0_{2}$ evolution in the $350 / 8$ treatment, which caused these tests to be significant.

As total PPF was increased from $\approx 10$ to $\approx 20 \mathrm{~mol} \cdot \mathrm{m}^{-2} \cdot \mathrm{day}^{-1}$, Chabot et al. (1979) found a linear slope of $0.23(\alpha=0.0001$, $\left.r^{2}=0.96\right)$ with SLW. Although this type of correlation cannot be made from our data due to the few treatments under 350 $\mu \mathrm{mol} \cdot \mathrm{m}^{-2} \cdot \mathrm{s}^{-1}$, increasing total PPF from 10 to $20 \mathrm{~mol} \cdot \mathrm{m}^{-2} \cdot \mathrm{day}^{-1}$ increased SLW by $30 \%$ (Table 2). Increasing the peak PPF from 175 to $350 \mu \mathrm{mol} \cdot \mathrm{m}^{-2} \cdot \mathrm{s}^{-1}$ also resulted in a $34 \%$ increase in SLW.

Reports in the literature of Pn rates for petunia seedlings and other genera are extremely limited. However, photosynthesis measurements made with mature leaves, which may not be directly comparable to the whole-shoot measurements used in this study, have been reported. In F. virginiana, Chabot et al. (1979) found that Pn rate was positively correlated with peak and total PPF. Other investigators (Bunce, 1983; Chatterton and Silvius, 1981) obtained higher photosynthetic rates in G. max by lengthening the Pn period while maintaining constant total PPF. Helianthus annus L. and Amaranths hypochondriacus L. responded similarly to changes in Pn period (Bunce, 1983). The expanding leaves used in our study responded more strongly to increasing peak PPF in conjunction with the Pn period (Table 2).

Shoot CHO content at the two-leaf stage, like the morphological and Pn measurements, was significantly modified by total PPF. Plants grown at 350/16, which had the highest DW-30\% higher than the mean of the other treatments (Table 2), often contained significantly more fructose, glucose, sucrose, starch, and total soluble sugars, resulting in a $30 \%$ to $90 \%$ higher total $\mathrm{CHO}$ content than in plants of the other treatments (Table 3). Acid invertase activity in these plants was increased by 50\% compared to other treatments. Growing plants under the 350/PE reduced levels of all sugars an average of $80 \%$ and reduced invertase activity an average of $100 \%$. In general, acid invertase activity and the amount of total CHO was positively correlated with seedling DW at the twoleaf stage (Tables 2 and 3).

Chatterton and Silvius $(1979,1981)$ investigated the effect of growing G. max at either 7-or 14-h photoperiods and Pn periods using treatments corresponding to our three treatments: $350 / 8$, 350/16, and 350/PE. Glycine max plants grown at the same peak PPF while doubling the Pn period from 7 to $14 \mathrm{~h}$ had a greatly reduced rate of starch production. Our data indicate that increasing the Pn period while holding the total PPF constant did not decrease the amount of starch but did decrease the total sugar content (Table 3). When the Pn period and total PPF were doubled, the sugar content was further increased. However, little consideration was given by Chatterton and Silvius $(1979,1981)$ to the fact that while doubling the Pn period, the total PPF was doubled as well.

Hordeum vulgare L. preferentially partitioned $\mathrm{CHO}$ into sugars when the total PPF was increased (Farrar and Farrar, 1987). Similar results were observed in our studies when sugar and starch content was expressed as a percentage of the total $\mathrm{CHO}$ produced by the plant at the two-leaf stage (Table 4). Doubling the peak PPF of a 16-h photoperiod from 175 to $350 \mu \mathrm{mol} \cdot \mathrm{m}^{-2} \cdot \mathrm{s}^{-1}$ increased partitioning into sugars by $25 \%$ and decreased partitioning into starch by $32 \%$. Increasing the photoperiod with an 8-h PE treatment decreased partitioning into sugar compared to the additional $8 \mathrm{~h}$ of $350 \mu \mathrm{mol} \cdot \mathrm{m}^{-2} \cdot \mathrm{s}^{-1}$ (Table 4$)$.

Britz et al. (1985) reported that doubling the Pn period and total PPF or doubling only the photoperiod reduced the rate of starch accumulation in Digitaria decumbens Stent. by $200 \%$ to $300 \%$. However, petunias grown continually in the 350/PE treatment, which had twice the photoperiod as those in 350/8, partitioned similar proportions of total $\mathrm{CHO}$ into sugars and starch (Table 4).

Increased acid invertase activity is closely associated with developing or rapidly expanding leaves (Claussen et al., 1985; Morris and Arthur, 1984, 1985). Seedlings grown with 350/16, which were developing at a faster rate than plants in other treatments, had 50\% higher invertase activity (Table 3 ). This increase may result in more rapid breakdown of sucrose into its constituent sugars, fructose and glucose, promoting rapid growth. Earlier findings, using supplemental high-pressure sodium, showed more rapid leaf unfolding in treatments with increased relative growth rate (Graper, 1990; Graper and Healy, 1991).

Total PPF was, in most cases, the dominant factor in increasing petunia seedling growth rate and the production and partitioning of CHO into sugars vs. starch in seedlings at the twoleaf stage. Increasing peak PPF increased SLW as previously reported (Chabot et al., 1979). However, the greatest increase in Pn was observed when peak PPF increased from 175 to 350 $\mu$ mol $\cdot \mathrm{m}^{-2} \cdot \mathrm{s}^{-1}$ while Pn was maintained at $8 \mathrm{~h}$ (Table 2). Most reports have indicated that total PPF was the dominant factor influencing Pn rate, but often these researchers failed to hold the Pn period or peak PPF constant, which could lead to erroneous conclusions (Bunce, 1983; Chabot et al., 1979; Chatterton and Silvius, 1980a, 1980b).

Increasing the photoperiod with low-level incandescent PE decreased total concentration of sugars and starch within the plant by $80 \%$ and $20 \%$, respectively, and decreased acid invertase activity by $50 \%$ and seedling DW, SLW, and $\mathrm{O}_{2}$ evolution at the two-leaf stage by $55 \%, 85 \%$, and $65 \%$, respectively, as compared to the other treatments. However, $\mathrm{CHO}$ partitioning 
Table 3. CHO measurements $\left(\mathrm{mg} \cdot \mathrm{dm}^{-2}\right)$ and acid invertase activity $\left(\mu \mathrm{mol} \cdot \mathrm{min}^{-1} \cdot \mathrm{dm}^{-2}\right)$ of Petunia $\times$ hybrida 'Red Flash' seedlings at the two-leaf stage of development for the four light treatments. (See Table 1 for treatment explanation.)

\begin{tabular}{lccccccc}
\hline \hline Treatment & Fructose & Glucose & Sucrose & $\begin{array}{c}\text { Total } \\
\text { soluble } \\
\text { sugar }\end{array}$ & Starch & $\begin{array}{r}\text { Total } \\
\text { CHO }\end{array}$ & $\begin{array}{r}\text { Enzyme } \\
\text { activity }\end{array}$ \\
\hline $175 / 16$ & $3.3 \mathrm{e}$ & $2.0 \mathrm{bc}$ & $0.8 \mathrm{~b}$ & $6.1 \mathrm{c}$ & $5.0 \mathrm{~b}$ & $11.1 \mathrm{c}$ & $88.3 \mathrm{~b}$ \\
$350 / 8$ & $4.6 \mathrm{~b}$ & $2.5 \mathrm{~b}$ & $1.5 \mathrm{a}$ & $8.6 \mathrm{~b}$ & $5.3 \mathrm{~b}$ & $13.9 \mathrm{~b}$ & $106.1 \mathrm{ab}$ \\
$350 / 16$ & $7.0 \mathrm{a}$ & $4.1 \mathrm{a}$ & $1.6 \mathrm{a}$ & $12.7 \mathrm{a}$ & $5.8 \mathrm{a}$ & $18.5 \mathrm{a}$ & $126.2 \mathrm{a}$ \\
$350 / \mathrm{PE}$ & $3.3 \mathrm{c}$ & $1.3 \mathrm{c}$ & $0.5 \mathrm{~b}$ & $5.1 \mathrm{c}$ & $4.5 \mathrm{c}$ & $9.6 \mathrm{c}$ & $53.3 \mathrm{c}$ \\
\hline
\end{tabular}

${ }^{2}$ Mean separation in columns by LSD, $P=0.05$.

Table 4. Carbohydrate partitioning (percentage of total CHO composed of starch or total sugar $\times 100)$ of Petunia $\times$ hybrids 'Red Flash' seedlings harvested at the two-leaf stage of development for the four light treatments. (See Table 1 for treatment explanation.)

\begin{tabular}{lcc}
\hline \hline Treatment & $\begin{array}{c}\text { Total soluble } \\
\text { sugar }(\%)\end{array}$ & Starch $(\%)$ \\
\hline $175 / 16$ & $47 \mathrm{~b}^{2}$ & $53 \mathrm{a}$ \\
$350 / 8$ & $54 \mathrm{ab}$ & $46 \mathrm{ab}$ \\
$350 / 16$ & $64 \mathrm{a}$ & $36 \mathrm{~b}$ \\
$350 / \mathrm{PE}$ & $48 \mathrm{ab}$ & $52 \mathrm{ab}$ \\
\hline
\end{tabular}

'Mean separation in columns by LSD, $P=0.05$.

between starch and sugar was consistent with the other two treatments receiving $10 \mathrm{~mol} \cdot \mathrm{m}^{-2} \cdot \mathrm{day}^{-1} \mathrm{PPF}$. Increasing the Pn period while holding the total PPF constant did not increase total $\mathrm{CHO}$ content or decrease total starch content. Only when total PPF was increased in conjunction with Pn period was total CHO content increased by $60 \%$ (Table 3 ) and seedling DW increased by $13 \%$ (Table 2 ).

Our research indicates that increasing the total PPF to seedlings in the greenhouse with supplemental lighting may in fact increase the seedling growth rate by increasing $\mathrm{CHO}$ partitioning into sugars rather than starch. Although total PPF is the dominant factor, increasing the peak PPF and Pn periods also play a critical role.

\section{Literature Cited}

Beaudry, R. M., R.F. Severson, C.C. Black, and S.J. Kays. 1989. Banana ripening: Implications of changes in glycolytic intermediate concentration, glycolytic and gluconeogenic carbon flux, and fructose 2,6-bisphosphate concentrations. Plant Physiol. 91:1436-1444.

Britz, S. J., W.E. Hungerford, and D.R. Lee. 1985. Photoperiodic regulation of photosynthate partitioning in leaves of Digitaria decumbens Stent. Plant Physiol. 78:710-714.

Bunce, J.A. 1983. Photosynthetic characteristics of leaves developed at different irradiances and temperatures: An extension of the current hypothesis. Photosyn. Res. 4:87-97.

Carpenter, W.J. and G.R. Beck. 1973. High intensity supplementary lighting of bedding plants after transplanting. HortScience 8:482-483.

Carpenter, W.J. and W.H. Carlson. 1974. Comparison of photoperiodic and high intensity lighting on the growth and flowering of Petunia hybrids Villm. Florist Rev. 154(3998):27-28, 68-71.

Chabot, B. F., T.W. Jurik, and J.F. Chabot. 1979. Influence of instantaneous lightflux density on leaf anatomy and photosynthesis. Amer. J. Bet. 66:94\&945.

Chatterton, N.J. and J.E. Silvius. 1979. Photosynthate partitioning into starch in soybean leaves. I. Effects of photoperiod versus photosynthetic period duration. Plant Physiol. 64:749-753.

Chatterton, N.J. and J.E. Silvius. 1980a. Acclimation of photosynthate partitioning and photosynthetic rates to changes in length of the daily photosynthetic period. Ann. Bet. 46:739-745.

Chatterton, N.J. and J.E. Silvius. 1980b. Photosynthate partitioning into leaf starch as affected by daily photosynthetic period duration in six Species. Physiol. Plant. 49:141-144.

Chatterton, N.J. and J.E. Silvius. 1981. Photosynthate partitioning into starch in soybean leaves. II. Irradiance level and daily photosynthetic period duration effects. Plant Physiol. 67:257-260.

Clauasen, W., B.R. Loveys, and J.S. Hawker. 1985. Comparative investigations on the distribution of sucrose synthase activity and invertase activity within growing, mature and old leaves of some $\mathrm{C}_{3}$ and $\mathrm{C}_{4}$ plant species. Physiol. Plant. 65:275280.

Delieu, T.J. and D.A. Walker. 1983. Simultaneous measurement of oxygen evolution and chlorophyll fluorescence from leaf pieces. Plant Physiol. 73:534-541.

Farrar, S. and J. Farrar. 1987. Effects of photon fluence rate on carbon partitioning in barley source leaves. Plant Physiol. Biochem. 25:541-548.

Grange, R.I. 1985. Carbon partitioning and export in mature leaves of pepper (Capsicum аппиит). J. Expt. Bet. 36:734-744.

Graper, D.F. 1990. Influence of supplemental irradiance on seedling growth and carbohydrate partitioning in petunia. PhD Diss., Univ. of Maryland, college Park. Graper, D.F. and W. Healy. 1987. Influence of supplemental irradiance and heat on Petunia hybrids seedling development in plug flats. HortScience 22:383. (Abstr.)

Graper, D.F. and W. Healy. 1989. Synergistic acceleration of Begonia semperflorens development using supplemental irradiance and soil heating. Acts Hort. 272:255259

Graper, D.F. and W. Healy. 1991. High pressure sodium irradiation and infrared radiation accelerate Petunia seedling growth. J. Amer. Hort. Sci. 116:435-438.

Gross, K.C. 1982. A rapid and sensitive spectrophotometric method for assaying polygalacturonase using 2-cyarroacetamide. HortScience 17:933-934.

Huber, S.C. and D.W. Israel. 1982. Biochemical basis for partitioning of photosynthetically fried carbon between starch and sucrose in soybean (Glycine max Merr.) leaves. Plant Physiol. 69:691-696.

Krizek, D.T., W.A. Bailey, H. Khreter, and R.C. Liu. 1974. Maximizing growth of vegetable seedlings in controlled environments at elevated temperature, light and $\mathrm{CO}_{2}$. Acts Hort. 39: 89-102.

Lang, D.M. and W.E. Healy. 1985. Supplemental irradiance of petunia 'Red Flash' from post germination to transplant. Colorado Grhs. Growers Res. Bul. 418:1-3.

Li, B.W. and P.J. Schuhmann. 1980. Gas-liquid chromatographic analysis of sugars in ready-to-eat breakfast cereals. J. Food Sci. 45:138-141.

Merritt, R.H. and H.C. Kohl, Jr. 1982. Effect of root temperature and photoperiod on growth and crop productivity efficiency on petunia. J. Amer. Soc. Hort. Sci. 107:997-1000.

Morris, D.A. and E.D. Arthur. 1984. Invertase activity in sinks undergoing cell expansion. Plant Growth Regulat. 2:2163-2167.

Morris, D.A. and E.D. Arthur. 1985. Invertase activity, carbohydrate metabolism and cell expansion in the stem of Phaseolus vulgaris L. J. Expt. Bot. 36:623633

Seeley, J.G. 1960. Petunias for sale S weeks after potting. New York State Flower Growers Bul. 170:1, 5-8.

Silvius, J. E., N.J. Chatterton, and D.F. Kremer. 1979. Photosynthate partitioning in soybean leaves at two irradiance levels. Plant Physiol. 64:872-875.

Walker, D. 1985. The use of the oxygen electrode and fluorescence probes in simple measurements of photosynthesis. Research Inst. for Photosynthesis, The Univ. of Sheffield, Sheffield, U.K. 